ICH 2019

International Conference on Humanities

\title{
CHALLENGES FACING SMALL AND MEDIUM TOURISM ENTERPRISES: A CASE STUDY IN KUALA SEPETANG
}

\author{
Ong Ke Shin (a)*, Chan Ngai Weng (b), Sharifah Rohayah Sheikh Dawood (c) \\ *Corresponding author
}

(a) School of Humanities, Universiti Sains Malaysia, keshinong@gmail.com

(b) School of Humanities, Universiti Sains Malaysia, nwchan@usm.my

(c) School of Humanities, Universiti Sains Malaysia, sdawood@usm.my

\begin{abstract}
Tourism is increasingly being viewed as a development strategy for regional growth, especially in areas experiencing rural decline and economic contraction. In Malaysia, most of the rural tourism related firms are small and medium enterprises (SMEs). While the role of SMEs in destination development is widely studied, the opportunities and challenges facing tourism SMEs are underexplored. In this regard, this study aims to identify and explore the opportunities and challenges that rural tourism SMEs, particularly those faced by boat operators and strategies adopted to overcome these problems. Qualitative approach using indepth interviews was adopted as a data collection strategy. The findings revealed that most of the boat operators based in Kuala Sepetang are male, with primary or secondary education. Reasons for the boat operators to ventured into tourism include to seek alternative income, to return to their hometown, or to satisfy their passion as a lifestyle entrepreneur. The main challenges the boat operators faced are (i) lack of qualified manpower; (ii) inadequate infrastructures; (iii) variable numbers of seasonal visitors; and (iv) competition among the boat operators.
\end{abstract}

2357-1330 @ 2020 Published by European Publisher.

Keywords: Small and medium enterprises, rural tourism, tourism challenges, Kuala Sepetang. 


\section{Introduction}

Tourism is increasingly popular as being perceived an alternative strategy in achieving prodigious economic growth and social development in rural area (Okech et al., 2012; Siow et al., 2015). Particularly at places that experiencing rural decline or places where traditional rural industries face challenges, tourism provides an alternative strategy to diversified economy and alternative source of income.

It is believed that rural tourism is a growth engine to improve local economy and diversify rural economies (Lane, 1994; Mshenga \& Richardson, 2013) as the introduction of tourism activities brought forth new income opportunities, as a catalyst of promoting growth of other surrounding sectors and industries of the local economy, increasing tax revenues for the government, thus induce economic growth (Koh \& Hatten, 2008).

\subsection{Tourism Entrepreneurs}

Tourism, as a composite industry that comprises of diverse stakeholders; such as government and its various agencies, hospitality sectors, tour operators, transport provider, food and beverage industry and retailer etc. Tourism entrepreneurs, which directly interact with tourist play a significant role and are major linkages of the supply chain. They help to unveil the potential of nature, cultural, heritage of an identified location and site that could be transformed into tourist attraction (Koh \& Hatten, 2008). Through their collective decision and efforts, the contents, components, outlook and projections of the development of tourism gradually materialized and evolved (Koh \& Hatten, 2008). Similarly, Komppula (2016) also suggest that tourism supply chain and entrepreneur play an important role in the overall destination competitiveness.

Tourism entrepreneur can be large scale, well established international company or small-scale and medium-sized enterprises (SMEs). Research by Jones and Haven-Tang (2005) and Lordkipanidze et al. (2005) suggests that although being "small scale", SMEs play an important role and acting as the back bone of the tourism industry as all tourism destination are commonly initiated by small enterprises (Getz \& Carlsen, 2005) and tourist industry is primarily made up of SMEs, especially at rural area. In view of their importance, the role of SMEs in tourism is being the subject of research and policy analysis due to its potential to contributing to combating poverty, increasing income and economic development (Mshenga \& Richardson, 2013).

\section{Problem Statement}

While the importance of SMEs in tourism development is being identified, the motivation and challenges faced by local tourism SMEs is understudy.

\subsection{Motivations of Local SME to involve in tourism}

It is common in most SMEs that the owner-manager is primarily responsible and the decision maker on the firm's priority, aims and policies making. Ateljevic and Doorne (2000) and Getz and Peterson (2005) suggest that SMEs keenness is in defending their choices of lifestyle over mere profit-driven alone. One the other hand, Middleton (1996) argue some business owners prone to prioritize business interests and 
profit-seeking than environmental concern. While the argument varies according to different study area, a convincing conclusion is that the various owner-managers' motivation and characteristic shape the respective firms' objectives and collectively the local SMEs shapes the tourism scape and affect the local tourism development. As such, understanding the characteristic and motivations of the local SMEs involving in tourism is crucial.

Besides, tourism SMEs is also constantly facing many other challenges. In comparison to well established large corporation, SMEs are more susceptible to market pressure, with lesser capital and lack of necessary skill which will eventually impede tourism development (Jones \& Haven-Tang, 2005). Similarly, Bramwell and Rawding (1996) also suggest that small firms are deprived of resources to be in tandem with the tempo of development and independently initiating on sustainability agenda. In Malaysia, SMEs play a very important role in rural tourism development particularly where local destination management organisation is absent, such as in the case of Kuala Sepetang. The local operators play an important role in promoting and diversifying tourism product. Concurrently, they are facing many other challenges. Hence, this study aims to understand the boat operator's motivation involving in tourism sector and the main challenges faced by tourism SMEs.

\subsection{Challenges facing tourism SME}

Besides, tourism SMEs is also constantly facing many other challenges. In comparison to well established large corporation, SMEs are more susceptible to market pressure, with lesser capital and lack of necessary skill which will eventually impede tourism development (Jones \& Haven-Tang, 2005). Similarly, Bramwell and Rawding (1996) also suggest that small firms are deprived of resources to be in tandem with the tempo of development and independently initiating on sustainability agenda. In Malaysia, SMEs play a very important role in rural tourism development particularly where local destination management organisation is absent, such as in the case of Kuala Sepetang. The local operators play an important role in promoting and diversifying tourism product. Concurrently, they are facing many other challenges. Hence, this study aims to understand the boat operator's motivation involving in tourism sector and the main challenges faced by tourism SMEs.

\section{Research Questions}

The primary research questions are

- What are the reasons for the SMEs owner-manager to venture into tourism industries?

- What are the main challenges facing Kuala Sepetang tourism SMEs?

\section{Purpose of the Study}

To understand the research purpose mentioned above, this study aims to

- Identify the main reasons for the tourism SMEs owner-manager to venture into tourism industries

- Examine the main challenges facing Kuala Sepetang tourism SMEs 


\section{Research Methods}

To achieve the objectives mentioned above, this research applied qualitative approach which allows a researcher to understand an individual or group's experience in a real world setting through the everyday or professional practices of the subject studied (Kvale, 2011). Specifically, this research applied semi structure interview as it enables the researcher to elicit data based on the research agenda while allowing the interviewees to express their own opinions and reflections.

\subsection{Sample}

In Malaysia, tourism activities can be classified into six categories, namely (1) Accommodation (2) Food \& Beverage (3) Transportation (4) Tour agent, tour operator \& tour guide (5) culture, recreation \& entertainment and (6) other tourism services (Hakimi et al., 2016). In Kuala Sepetang, the boat operator that falls under categories (3) and (4) plays a crucial role in the tourism development as they provide boat services and tour guide services. In view of the research objectives and the crucial role of owner-manager of boat operator, this study aims to focus on the owner-manager of boat operator. Thus, homogeneous purposeful sampling which focuses on one specific group with specific characteristic was applied as the sampling method (Palinkas et al., 2015). Contrary to probability sampling which aim to generalising the findings to the population, purposeful sampling aims to focus on a specific group of people who possess characteristics or behaviours that are relevant to the research objectives. In this study the key criteria selecting the informants are (1) owner-manager of tourist boat service operator (2) Kuala Sepetang based business operators. A total of six interviewees fulfilling the above criteria were identified in this study. These selected participants are key informants equipped with important source of information and knowledge. The interviewees were contacted individually between December 2018 to April 2019. Prior each interview, a preliminary meeting was conducted to explain the objectives of the research and an interview session will then be arranged with the interviewee who agreed to involved in the research. All six owner-manager of tourist boat service operator were interviewed in this study. Interview questions were mainly focused on the owner manager personal background, main reasons for the owner-manager to venture into tourism industries and the challenges they faced.

\subsection{Data Analysis}

All six-interviews, range from one hour to three hours were voice recorded with the consent from the interviewees. The interviews were then transcribed verbatim for data analysis. In this study, thematic analysis, which is a "method for systematically identifying, organizing, and offering insight into patterns of meaning (themes) across a data set"(Braun \& Clarke, 2012) was applied to as data analysis method.

\section{Findings}

\subsection{Profile of Kuala Sepetang Boat Operator}

All the six owner-manager of the boat operators in Kuala Sepetang were owned by men. Most are local resident residing in the village except for one, who is from Taiping - an adjacent town to Kuala 
Sepetang. However, it is worth noting that while all owner-manager are man, the operation and management of the business are often supported by family members, such as siblings, spouse and children of the owner. Previous research by (Getz \& Carlsen, 2005) also made a similar observation, in which tourism SMEs usually rely on family members for labour and resources. The profile of interviewees are shown in Table 1.

Table 01. Profile of interviewees

\begin{tabular}{|c|c|c|c|c|}
\hline $\begin{array}{c}\text { Boat and Tour } \\
\text { Operator }\end{array}$ & Gender & Education Level & Residing at & $\begin{array}{c}\text { Number of } \\
\text { boats owned }\end{array}$ \\
\hline 1 & Male & Secondary & Kuala Sepetang & 4 \\
\hline 2 & Male & Higher education & Taiping & 2 \\
\hline 3 & Male & Primary & Kuala Sepetang & 2 \\
\hline 4 & Male & Secondary & Kuala Sepetang & 3 \\
\hline 5 & Male & Primary & Kuala Sepetang & 2 \\
\hline 6 & Male & Secondary & Kuala Sepetang & 1 \\
\hline
\end{tabular}

\subsection{Motivation to involve in tourism industries}

Entrepreneur motivation is a crucial element affecting ownership, operation methods and direction of the firm (Getz \& Carlsen, 2005). In this study, motivation to involve in tourism industries varies for each of the owner-manager and is categorized into three broad categories.

First, is to explore the possibility of tourism as an alternative source of income, especially when the fishing and shellfish industry are facing several challenges. One of the boat owners, who is also a fisherman explained: "The tourism industry at Kuala Sepetang is booming a few years ago, and the cockles harvest was not doing well, so I would like to give it a try......to see if I can seize this opportunity and earn more money. I cannot rely on the cockle industry alone."

Similarly, another owner-manager, who is also a middle man of the fishing trade also view tourism as an opportunity for alternative income. He explained: "As middleman, we do not have to go fishing every day , so I can make use of my free time and take tourist around...... there are many tourists who come here during school holidays, we can get some income from that."

Another two owner-manager ventured into tourism in order to return to their home town. They were previously working in Kuala Lumpur and Johor respectively, explained that they left Kuala Sepetang ages ago due to limited job opportunity at the time. When Kuala Sepetang tourism blooms, they perceived it as a good opportunity to return to their hometown.

Lastly, one operator from Taiping decided to start a tourism business at Kuala Sepetang as he appreciates nature and would like to spend most of his retirement sharing his passion with tourist. This is classified as "lifestyle entrepreneurs" (Getz \& Peterson, 2005; Gibson et al., 2005; Koh \& Hatten, 2008) which refer to those who ventured into tourism to satisfying their intended passion and lifestyles with little or the absence of financial gain or economic consideration.

\subsection{Challenges faced - shortage of qualified manpower}

Shortage of operator or staff with tourism related qualifications was mentioned by all ownermanagers. In Malaysia, it is compulsory for tourist guide to obtaining necessary license from the Ministry 
of Tourism and Culture Malaysia (MOTAC). There are two types of tourist guide licenses, namely (1) Green Badge License for local nature tourist guide (2) Blue Badge License for city tourist guide.

While all the owner-manager emphasises that they possess license for tourist boat issued by the Marine Department of Malaysia, only one of the owner-manager possess Green Badge License. Another three owner-managers rely on tourist guide from Taiping serving on part time basis. While another two owner-manager hire locals and at times their own children as "tourist guide" to provide some simple introductions and explanations to the tourist. While research by Shareena et al. (2018) suggest local community from the mangrove destination would be a great candidate to be the tourist guide as they are familiar with the area and the ecosystem thus able to contribute to local economy; nevertheless, interview with several owner-manager revealed that it is challenging for the local community to play the role of a licensed tourist guide. The interviewees explained the main reason obstructing them from obtaining a tourist guide license is due to their low literacy and limited language proficiency which pose a challenge.

Owner-manager 1 says that: "The government give some training, after attending and taking the exam you can get a tourist guide license. I attended half day and I "ran away". I have no idea what they are talking......we are not suitable to talk (to tourist), we just can't open our mouth. We have to rely on tourist guide from Taiping, but we got no choice. It's better to let those who can talk to do it."

While relying on licensed tourist guide based in Taiping seems to provide a temporary solution, several owner-managers relay the setback on relying on non-local tourist guide. As these licensed tourist guides are based in Taiping and are hired when demanded, they are not stationary at the village. Hence, tourists visiting Kuala Sepetang without prior booking are often not guided by licensed tourist guide. While some local villagers are able to provide some basic introductions and explanations, many do not converse in English and some has limited knowledge as compared to licensed tourist guide.

Owner-manager 3, an operator with primary school education qualification found it challenging to cope with English speaking tourist. He explained: "I don't speak English, so I cannot introduce the place or the mangrove to the foreigners. I just show them around with the boat without explanation.”

Owner-manager 4 stated: "I ask my daughter to gather information on fireflies from the internet, but there is so many information on fireflies, some says the light (of the fireflies) is green, some says it is yellow. It is very confusing, and we do not know which is correct. We are not scientist. At times, tourist would ask and we are not sure."

\subsection{Challenges faced - inadequate infrastructures}

All six-owners agreed that the inadequacy of facilities such as jetty for tourist, limited parking space around the village remain an important challenge for them. Owner-manager 6 mentioned: "Since the tourism industry started around 2010, we have been relying on private jetty. There is no public jetty for tourist although we have proposed to the local and state government several times. This jetty is not suitable for tourists especially old folks and children, and the jetty is getting old." Owner-manager 3 further explained: "There were once, not only once, but several times that the boat operators got into conflict over the use of this jetty. There was fight when certain party was trying to dominate the jetty and the tourism business here. The jetty belongs to no one and nobody are supposed to have a definite says on this." 
All the interviewees mentioned that there is a clear absence of public toilet near the jetty. Ownermanager 1: "I think it is an embarrassment, we invite tourist to come here but we couldn't even provide a proper toilet. Sometimes our customers have to use toilet of nearby restaurant and this clearly upset the restaurant owner."

Limited parking space also caused inconvenience to the tourist as well as local residence. There were no public car park and they have to park their car along the street that sometimes blocks the entrance of villager's house, especially during peak season. Condition worsen when irresponsible parking blocked tourist buses that led to serious traffic congestion within the small village. Besides, according to all the interviewees, Kuala Sepetang is a coastal village regularly affected by floods especially during raining season, the condition were exacerbated during high tide. This has cause inconvenience to the tourist and visitors alike, thus affecting their business.

\subsection{Seasonality of tourism demand}

Another significant challenge facing most owner-manager is the drastic fluctuation of tourist and visitor number to Kuala Sepetang. The boat operator received more visitors at certain time of the year, while there are times they received very few or totally without any tourist at all. Baum (1999) highlighted the two causes of tourism seasonality 1) seasonality of natural causes and 2) seasonality of institutional cause, which was echoed by the owner-managers. River cruises, eagle and firefly watching and visits to Charcoal Kiln are the several main attractions of Kuala Sepetang, and most of the tourism activities are outdoor-bound thus significantly influenced by weather patterns. While Malaysia is not affected by drastic change in temperature like other temperate countries, there remained fewer tourists visiting Kuala Sepetang during rainy season. Other than the weather, the business of the boat operator is also affected by institutional seasonality, which refers to causes related to human decision or human behaviour. It is a complex "outcome of a combination of religious, cultural, ethnic and social factors" (Baum, 1999). During the interview, all the owner-manager of the boat operator cited that school holiday and public holidays are the major affecting factors. The peak season usually falls on school holiday and public holiday, thus experiencing hectic workload. To cope with the high demand during the peak season, some boat operators carry passenger beyond the permitted capacity of the boat, and some would shorten the tour duration to save time for more extra trips. While boat operators enjoy their robust business during peak season, business is slow during low season or weekdays, thus hindering their employment of full time staff.

Owner-manager 1 stated: "I cannot afford a full-time tourist guide, sometimes I hardly get any business in one day during low season. I can only hire tourist guide and boatman on part time basis and I pay them based on number of trip they make. During off season, they have to work elsewhere". Similarly, owner-manager 3 also mentioned: "We cannot solely rely on tourism industry; I have to work as a fisherman at the same time as the tourism industry is not consistent. It is very hard to predict, we never know."

Other than school holiday and public holiday, a few owner-managers mentioned that rabies outbreak around July 2017 has seriously impacted their business. Owner-manager 5 stated: "The whole village was very quiet after the rabies outbreak reported in the media; many schools called and cancel their booking with us because they were concern with the students' safety. We hardly get any business for about three months, until the outbreak slowly forgotten by people." 


\subsection{Challenges faced - competition among boat operators.}

Competition among the six tour operators is inevitable as they are offering similar services and targeting the same group of customers. Interviews with the owner-manager of boat operators affirmed the intense and unhealthy competitions among boat operators, in which they compete by slashing price of identical tour package.

Owner-manager 6 stated: "In the past we used to charge RM 30 per head for a full package, but the price was lowered to RM 25 and sometimes even as low as RM 20. One of the tour operators began lowering prices and we got no choice but to follow, but how do we still manage to make earnings when the price is so low? We have to reduce our cost by shortening the tour duration and taking a shorter route. Sometimes when the group is small, we only send one boatman out. He will navigate the boat and explain to the tourist concurrently. We cannot afford to hire an additional tourist guide."

However, another owner-manager who believes in providing quality services persisted in not entangling in the price war but to compete on value rather than pricing. He believed that he can compete by targeting on different customer group that yearned for in-depth tour. Hence, he differentiates his company from others by providing better services, in-depth and hands-on experiences. All interviewees raised concern over the unhealthy competition among the boat operators by slashing tour package pricing.

\section{Conclusion}

\subsection{Key findings}

Tourism in Kuala Sepetang is booming. While the tourism industry is not an alternative form of income that replaces the traditional fishing industry in the village, it complements the traditional fishing industry and allows the fisherman to earn additional income. Other than earning additional income, there are those who ventured into the tourist industry for their desired lifestyle - to appreciate nature or to live and work in their hometown.

Contrary to those observed in Semporna (Siow et al., 2015), where most of the owner-manager of the tour operator are outsiders which bring the concern on economic leakage, whereas in Kuala Sepetang, most of the owner-manager consist of locals. This could be due to the local community's familiarity of the local environment, especially the mangrove and some of them is involving in fishing activity thus capable of operating a boat, enabling to providing boat service easily. While it is positive that the owner-manager are from the local community and playing an important role in the local destination development, shortage of skilled man power such as license tourist guide, conflict and unhealthy competition among the boat operators threatens the service quality, affecting tourist satisfaction and negative image of the tourism destination in the long run. Government can play an important role to improve the public infrastructure and facilities such as jetty and parking area, encourage more local guide to received professional tour guide training to ensure the destination image and competitiveness.

\subsection{Limitations and future research directions}

While this study contributes to a better understanding of the motivation for owner-managers of boat operators based in Kuala Sepetang to venturing into tourism industry and their challenges encountered, this 
research does not investigate the relationship between the owner-manager's motivation and their response towards challenges faced. Therefore, it is suggested that future research can further investigate the association between the motivations and responses of the owner-manager.

\section{References}

Ateljevic, I., \& Doorne, S. (2000). 'Staying within the fence': Lifestyle entrepreneurship in tourism? Journal of Sustainable Tourism. https://doi.org/10.1080/09669580008667374

Baum, T. (1999). Seasonality in Tourism: Understanding the Challenges. Tourism Economics. https://doi.org/10.1177/135481669900500101

Bramwell, B., \& Rawding, L. (1996). Tourism marketing images of industrial cities. Annals of Tourism Research. https://doi.org/10.1016/0160-7383(95)00061-5

Braun, V., \& Clarke, V. (2012). APA handbook of research methods in psychology. Quantitative, qualitative, neuropsychological, and biological. https://doi.org/10.1037/13620-004

Getz, D., \& Carlsen, J. (2005). Family business in tourism. State of the art. Annals of Tourism Research, 32(1), 237-258. https://doi.org/10.1016/j.annals.2004.07.006

Getz, D., \& Peterson, T. (2005). Growth and profit-oriented entrepreneurship among family business owners in the tourism and hospitality industry. International Journal of Hospitality Management, 24(2), 219-242. https://doi.org/10.1016/j.ijhm.2004.06.007

Gibson, L., Lynch, P. A., \& Morrison, A. (2005). The local destination tourism network: Development issues. Tourism and Hospitality, Planning and Development, 2(2), 87-99. https://doi.org/10.1080/14790530500171708

Hakimi, M., Hussain, M., \& Ismail, H. N. (2016). Different Perspectives on Small Tourism Firms in Malaysia Different Perspectives on Small Tourism Firms in Malaysia, (May).

Jones, E., \& Haven-Tang, C. (2005). Tourism SMES, service quality and destination competitiveness. In Tourism SMES, Service Quality and Destination Competitiveness.

Koh, K. Y., \& Hatten, T. S. (2008). The Tourism Entrepreneur The Tourism Entrepreneur: The Overlooked Player in Tourism Development Studies, 6480, 20-48. https://doi.org/10.1300/J149v03n01

Komppula, R. (2016). The role of different stakeholders in destination development. Tourism Review, 71(1), 67-76. https://doi.org/10.1108/TR-06-2015-0030

Kvale, S. (2011). Doing Interviews. Doing Interviews. https://doi.org/10.4135/9781849208963

Lane, B. (1994). What is rural tourism? Journal of Sustainable Tourism, 2(1-2), 7-21. https://doi.org/10.1080/09669589409510680

Lordkipanidze, M., Brezet, H., \& Backman, M. (2005). The entrepreneurship factor in sustainable tourism development. Journal of Cleaner Production, 13(8), 787-798. https://doi.org/10.1016/j.jclepro.2004.02.043

Middleton, V. T. C. (1996). Toward sustainable tourism - a marketing perspective. Journal of Vacation Marketing. https://doi.org/10.1177/135676679600200201

Mshenga, P. M., \& Richardson, R. B. (2013). Micro and small enterprise participation in tourism in coastal Kenya, 667-681. https://doi.org/10.1007/s11187-012-9449-5

Okech, R., Haghiri, M., \& George, B. (2012). Rural Tourism as a Sustainable Development Alternative: An Analysis with Special Reference to Luanda, Kenya. CULTUR: Revista de Cultura e Turismo, 6(3), 36-53.

Palinkas, L. A., Horwitz, S. M., Green, C. A., Wisdom, J. P., Duan, N., \& Hoagwood, K. (2015). Purposeful Sampling for Qualitative Data Collection and Analysis in Mixed Method Implementation Research.

Shareena, S., Azis, A., Sipan, I., Sapri, M., \& Muin, A. (2018). Creating an innocuous mangrove ecosystem : Understanding the in fl uence of ecotourism products from Malaysian and international perspectives, 165(September), 416-427. https://doi.org/10.1016/j.ocecoaman.2018.09.014

Siow, M.-L., Ramachandran, S., Shuib, A., \& Mohammad Afandi, S. H. (2015). Adapting evidence-based intervention in rural tourism policies. Worldwide Hospitality and Tourism Themes, 7(5), 473-485. https://doi.org/10.1108/WHATT-06-2015-0031 